\title{
PENGARUH TINGKAT PENDIDIKAN, PENDAPATAN PER KAPITA DAN PENGANGGURAN TERHADAP KEMISKINAN DI DKI JAKARTA
}

\author{
Darma Rika S. \\ Munawaroh* \\ Dita Puruwita*
}

\begin{abstract}
This research was aimed at describing connections between education, income per capita and unemployment to poverty in Indonesia. In this research, the data were taken from Badan Pusat Statistik (BPS). The analysis use qualitative and quantitative. Qualitative analysis described in descriptive about education, income per capita, unemployment and poverty in Indonesia. The quantitative analysis used Ordinary Least Squares (OLS) with secondary data. The Regression of research results show that: (1) education has a negative influence to poverty and the effect statistically significant. (2) income per capita has a negative influence to poverty and the effect statistically significant. (3) unemployment has a positive influence to poverty and the effect statistically significant.
\end{abstract}

\section{PENDAHULUAN}

Di negara-negara berkembang, perhatian utama terfokus pada dilema kompleks antara pertumbuhan versus distribusi pendapatan. Keduanya sama-sama penting namun sulit diwujudkan secara bersamaan. Pengutamaan yang satu akan menuntut dikorbankannya yang lain. Pembangunan mensyaratkan Gross Domestic Product (GDP) yang lebih

Darma Rika S., Munawaroh \& Dita Puruwita. Dosen Fakultas Ekonomi Universitas Negeri Jakarta tinggi, dan untuk itu tingkat pertumbuhan yang lebih tinggi merupakan pilihan yang harus diambil.

Namun yang menjadi masalah bukan hanya soal bagaimana caranya memacu pertumbuhan, tetapi juga siapa yang pantas melakukan, kalangan elit kaya yang minoritas, ataukah mayoritas rakyat yang miskin. Seandainya yang diserahi wewenang itu adalah kelas kaya, maka mereka akan mampu memacu 
pertumbuhan dengan baik, akan tetapi kemungkinan kondisi ketimpangan pendapatan dan kemiskinan absolut tidak dapat segera teratasi. Tetapi jika yang dipilih adalah mayoritas rakyat miskin, segenap hasilnya harus dibagi secara lebih merata, dan hal ini yang menyebabkan pertumbuhan ekonomi tidak terlalu tinggi.

Dewasa ini diakui secara luas bahwa pertumbuhan GDP, yang diukur secara konvensional, tidak memuaskan sebagai tujuan dan keberhasilan pokok dari pembangunan. Diantara banyak alasan mengapa ini diterima secara umum adalah sebagai berikut. Pertama, banyak negara berkembang yang telah mengalami laju pertumbuhan GDP yang pesat, secara berbarengan juga mengalami pengangguran yang meningkat. Laju pertumbuhan lapangan kerja ternyata jauh lebih lamban dari laju pertumbuhan GDP, dan pertumbuhan pesat dalam GDP sering pula disertai oleh kepincangan dalam pembagian pendapatan yang makin besar (kemiskinan relatif) dan, dalam beberapa hal, kemiskinan absolut yang makin besar daripada beberapa golongan.
Gejala bertambahnya pengangguran dan pembagian pendapatan yang makin pincang saling berkaitan, artinya kedua tingkat pendapatan (relatif atau absolut) yang lebih rendah terutama terdapat di antara mereka yang tidak berhasil memperoleh pekerjaan, sedangkan hasil-hasil dari pertumbuhan GDP terpusat pada mereka yang mempunyai pekerjaan. Pengangguran terbuka bukan merupakan ukuran yang memuaskan bagi kemiskinan, karena para penganggur terbuka pada umumnya lebih baik keadaannya, sedangkan mereka yang benar-benar miskin tidak mungkin menganggur. Tetapi kemiskinan dapat dijadikan ukuran memadai bagi sebagian dari masalah kesempatan kerja, karena kelebihan persediaan tenaga kerja yang mencari pekerjaan tercermin pada penghasilan rendah yang disebabkan tidak adanya lapangan kerja sama sekali (pengangguran terbuka), kekurangan pekerjaan (jam kerja yang sedikit), atau pekerjaan dengan produktivitas yang sangat rendah (sumbersumber daya pelengkap yang tidak mencukupi atau produktivitas rendah yang disebabkan oleh tingkat hidup yang rendah) 
Seseorang dianggap pengangguran jika dia tidak bekerja sama sekali, atau sedang mencari pekerjaan dan siap bekerja tetapi tidak memperoleh pekerjaan. Sedangkan tingkat pengangguran adalah perbandingan jumlah penganggur dengan jumlah angkatan kerja yang dinyatakan dalam persen.

Peningkatan pengangguran di negara-negara yang sedang berkembang disebabkan oleh lambatnya pertumbuhan kesempatan kerja daripada pertumbuhan yang cepat dari angkatan kerja. Program-program untuk meningkatkan kesehatan, nutrisi, pendidikan, pembangunan perkotaan, distribusi pendapatan, dan kesempatan bagi wanita dapat mengurangi kelahiran dan pertumbuhan populasi, sehingga akan menurunkan angkatan kerja berumur 15-20 tahun.

Beberapa orang masih menyangkal bahwa pendidikan juga merupakan salah satu aspek yang penting dalam kesejahteraan. Pemerintah dapat memainkan peranan penting dalam meningkatkan kesejahteraan rakyatnya dengan merancang program-program yang berhubungan dengan pendidikan sedemikian rupa sehingga golongan miskin juga dapat ikut menikmatinya, karena hal ini juga dapat menurunkan ketidakmerataan distribusi pendapatan dalam masyarakat.

Apabila pemerintah kurang mendukung pendidikan dan pelatihan, maka hanya sedikit dari penduduk yang berpend apatan rendah yang mendapat kesempatan untuk meningkatkan pendapatan, atau dengan kata lain meningkatkan tingkat kesejahteraannya.

Di Indonesia, layaknya di negara berkembang lainnya, pendidikan dianggap orang tua sebagai sarana penghubung untuk meningkatkan kesejahteraan. Dan tingkat pendidikan merupakan faktor yang sangat penting dalam menentukan pendapatan seumur hidup.

Badan Pusat Statistik (2000) faktor utama penyebab kemiskinan terutama karena faktor alamiah. Seseorang menjadi miskin karena mereka dilahirkan dari keluarga miskin. Kemiskinan menyebabkan mereka tidak hanya kesulitan dalam memenuhi kebutuhan dasar tetapi juga tidak mampu mengembangkan status sosialnya. Dengan kata lain, kemiskinan merupakan mata rantai yang bila tidak diputus akan 
menyebabkan kemiskinan tersebut selalu ada.

\section{KAJIAN TEORI}

\section{Kemiskinan}

Kemiskinan merupakan permasalahan yang selalu timbul di negara berkembang dan negara sedang berkembang, termasuk Indonesia. Walaupun sudah banyak program-program yang ditujukan dalam upaya penghapusan kemiskinan, namun masalah ini tak kunjung selesai juga. Sulitnya penyelesaian masalah ini disebabkan karena permasalahan yang melibatkan penduduk miskin ternyata sangat kompleks.

Mencari pengertian
kemiskinan bukanlah hal yang
mudah. Kemiskinan sebagai suatu
gejala sosial akan berbeda dengan
kemiskinan sebagai gejala ekonomi.
Kemiskinan sosial (cultura) lebih
banyak berkaitan dengan sikap
hidup penduduk miskin yang tidak
mempunyai keinginan untuk maju
dan berusaha memperbaiki taraf
kehidupan. Sedang kemiskinan
ekonomi merupakan suatu gejala
yang terjadi di sekitar lingkungan
penduduk miskin dan biasanya
dikaitkan dengan masalah
pendapatan.

Konsep kemiskinan pada dasarnya berkaitan dengan tingkat pendapatan dan kebutuhan. Kebutuhan hanya dibatasi pada kebutuhan pokok atau kebutuhan dasar minimum yang memungkinkan seseorang dapat hidup secara layak. Jika tingkat pendapatan tidak dapat memenuhi kebutuhan minimum, maka orang atau rumah tangga tersebut dikatakan miskin. Dengan kata lain, kemiskinan dapat diukur dengan membandingkan tingkat pendapatan orang atau rumah tangga dengan tingkat pendapatan yang diperlukan untuk memenuhi kebutuhan minimum. Dengan demikian, tingkat pendapatan minimum merupakan batas antara keadaan miskin dengan tidak miskin atau sering disebut dengan garis kemiskinan. Konsep ini dikenal sebagai kemiskinan mutlak (absolut).

Sebaliknya, walaupun tingkat pendapatan sudah mencapai tingkat kebutuhan dasar minimum, tetapi masih kecil dibandingkan dengan tingkat pendapatan masyarakat sekitarnya, maka orang atau rumah tangga tersebut masih berada dalam keadaan miskin. Konsep ini dikenal sebagai kemiskinan relative. Kemiskinan relatif berkaitan dengan masalah pembangunan yang 
bersifat struktural, yaitu kebijaksanaan yang belum seimbang sehingga menyebabkan ketimpangan distribusi pendapatan. Masalah distribusi pendapatan atau kemiskinan relatif berkaitan erat dengan masalah kemiskinan absolut karena kemiskinan absolut merupakan akibat dari ketimpangan distribusi pendapatan. Jika kesenjangan pendapatan tinggi maka jumlah penduduk miskin pun akan tinggi. Kemiskinan relatif akan selalu timbul selama masih ada ketimpangan distribusi pendapatan.

Kemiskinan absolut diartikan sebagai suatu keadaan dimana tingkat pendapatan absolut dari suatu masyarakat tidak mencukupi untuk memenuhi kebutuhan pokoknya seperti: pangan, sandang, pemukiman, kesehatan, dan pendidikan. Besarnya masalah kemiskinan absolut tercermin dari jumlah penduduk yang tingkat pendapatan atau konsumsinya berada di bawah tingkat minimum yang telah ditetapkan. Bank Dunia dalam World Development Report (1990) mendefinisikan keadaan miskin sebagai berikut "Poverty is concern with absolute standard of living of a part of society -the poor- in equality refers to relative living standard across the whole society".

Tahap penting dalam usaha pengukuran skala kemiskinan adalah menentukan ukuran garis kemiskinan yang secara umum dapat diterapkan di seluruh negara. Dalam usaha menentukan kemiskinan absolut diperlukan pola taraf konsumsi minimum untuk melangsungkan kehidupan. Hal ini menjadi masalah, sebab ukuran melangsungkan kehidupan tidak dapat didefinisikan secara jelas. Dalam ukuran yang lebih sempit kita memerlukan data harapan hidup yang berlaku di dalam lingkungan tertentu. Pada saat ini ukuran harapan hidup (life expectancy) di negara-negara berkembang tergolong sangat rendah dan tidak menyediakan dasar untuk menghitung kebutuhan minimum manusia. Peningkatan tingkat harapan hidup akan menyebabkan kebutuhan untuk konsumsi akan meningkat. Dengan kata lain tingkat konsumsi riil seperti makanan, lingkungan hidup yang sehat dan kebutuhan akan nutrisi juga meningkat.

Untuk menentukan ukuran kemiskinan absolut kadang-kadang ukuran tingkat kebutuhan biologis tidak terlalu tepat. Dalam beberapa 
kasus kemiskinan, ukuran kebutuhan biologis tidak mencerminkan suatu kemiskinan absolut. Jadi konsep garis kemiskinan hanya dapat berjalan ketika kita berada dalam ruang lingkup sosial. Bila dalam ruang lingkup sosial tertentu menerapkan suatu standar hidup yang lebih tinggi maka individu berusaha menyesuaikan standar sosial berdasarkan standar lingkungannya. Konsep garis kemiskinan ini menjadi bahan perdebatan diantara beberapa negara. Hal ini disebabkan karena konsep ini mencerminkan perbedaan taraf ekonomi, sosial dan pembangunan ekonomi. Dengan kata lain, ukuran kemiskinan ini akan berubah menurut waktu.

Dalam beberapa penelitian, ukuran yang paling banyak dipakai dalam pengukuran garis kemiskinan adalah total belanja konsumsi yaitu total konsumsi yang memenuhi kebutuhan dasar sebesar 2.250 kalori tiap hari per individu. Walaupun jumlah orang yang berada di bawah garis kemiskinan dalam standar tersebut selalu berubah dari tahun ke tahun, tetapi dipastikan kira-kira 40-50\% dari total populasi dunia berada di bawah garis kemiskinan.
Tetapi berdasarkan pendekatan income based, untuk menentukan kemiskinan, teori ini tidak secara eksplisit menghitung kebutuhan individu di dalam pemenuhan tingkat minimum jasajasa publik seperti kesehatan, pendidikan, kebutuhan akan air bersih, dan sanitasi. Hal-hal tersebut merupakan bagian yang penting di dalam konsep kemiskinan secara utuh dan merupakan hal yang sangat penting di dalam rancangan program pengurangan kemiskinan.

\section{Tingkat Pendidikan}

Tingkat

pendidikan merupakan faktor penting yang mempengaruhi distribusi pendapatan dan kemiskinan. Psacharopoulos dalam Kokila (2000), telah menekankan peranan pendidikan di dalam pengurangan ketimpangan dan kemiskinan. Hal ini sejalan dengan Dejanvry dan Sadoulet dalam Kokila (2000) yang menyatakan bahwa pendidikan mengurangi ketimpangan dan kemiskinan secara langsung, yaitu: dengan meningkatkan produktivitas bagi golongan miskin, memperbaiki kesempatan mereka untuk memperoleh pekerjaan dengan upah yang lebih baik, dan membuka jalur hubungan vertikal bagi anak- 
anak mereka. Secara tidak langsung, pendidikan memberikan kemampuan yang lebih bagi golongan miskin untuk memperoleh bagian mereka dari total pendapatan.

Beberapa orang masih menyangkal bahwa pendidikan juga merupakan salah satu aspek yang penting dalam kesejahteraan. Pemerintah dapat memainkan peranan penting dalam meningkatkan kesejahteraan rakyatnya dengan merancang program-program yang berhubungan dengan pendidikan sedemikian rupa sehingga golongan miskin juga dapat ikut menikmatinya, karena hal ini juga dapat menurunkan ketidakmerataan distribusi pendapatan dalam masyarakat.

Apabila pemerintah kurang mendukung pendidikan dan pelatihan, maka hanya sedikit dari penduduk yang berpendapatan rendah yang mendapat kesempatan untuk meningkatkan pendapatan, atau dengan kata lain meningkatkan tingkat kesejahteraannya. Menurut Gillis (2000) Terdapat dua alasan mengapa pendidikan itu penting:

1. Terdapat banyak permintaan yang tinggi untuk pendidikan, hal ini terjadi karena masyarakat dimana saja percaya bahwa pendidikan dapat memberikan keuntungan bagi diri mereka dan juga anak-anak mereka. Namun di negara-negara berkembang masih banyak yang belum dapat menampung permintaan pendidikan, karena belum banyak terdapat sekolah terutama di pedesaan dan daerah-daerah terpencil lainnya, sehingga masih banyak terdapat penduduk yang belum dapat mengenyam pendidikan.

2. Alasan lainnya adalah karena telah banyak dilakukan observasi yang menyebutkan bahwa dengan tingkat pendidikan yang tinggi maka pendapatan dan kedudukan sosial seseorang di masyarakat akan dapat terangkat. Walaupun tidak semua orang yang menyelesaikan sekolahnya lebih baik dari yang tidak bersekolah atau menyelesaikan sekolahnya, namun rata-rata mereka yang menyelesaikan sekolahnya menghasilkan pendapatan lebih banyak. Oleh karena itu orangorang di seluruh dunia menyadari hal itu sehingga mereka berusaha agar anakanak mereka nanti mendapatkan pendidikan yang tinggi. Pada 
negara-negara berkembang kini mulai memperhatikan pentingnya pendidikan karena pendidikan dianggap dapat meningkatkan pembangunan.

\section{Pendapatan per kapita}

(1994) mengatakan bahwa pembangunan ekonomi adalah perubahan spontan dan terputusputus dalam keadaan stasioner yang senantiasa mengubah dan mengganti situasi keseimbangan yang ada sebelumnya. Pembangunan ekonomi ini mengacu pada masalah negara berkembang, sedangkan pertumbuhan ekonomi adalah perubahan jangka panjang secara perlahan dan mantap yang terjadi melalui kenaikan tabungan, pendapatan dan pertumbuhan ekonomi mengacu kepada masalah di negara maju.

Kamus ekonomi Everyman membuat perbedaan di atas lebih eksplisit, umumnya pembangunan ekonomi berarti pertumbuhan ekonomi. Lebih khusus, istilah itu tidak dapat dipergunakan untuk menggambarkan tindakan kuantitatif. Perekonomian yang sedang berkembang (seperti laju kenaikan di dalam pendapatan per kapita) tetapi perubahan ekonomi, sosial atau perubahan lain yang mengarah kepada pertumbuhan sehingga pertumbuhan dapat diukur dan objektif, yang menggambarkan perluasan tenaga kerja, modal, volume perdagangan dan konsumsi. Pertumbuhan ekonomi dapat dipergunakan untuk menggambarkan faktor-faktor penentu yang mendasari pertumbuhan ekonomi seperti, perubahan dalam teknik produksi, sikap masyarakat dan lembaga, perubahan tersebut dapat menghasilkan pertumbuhan ekonomi.

Sadono Sukirno menyimpulkan istilah dari pembangunan ekonomi dan pertumbuhan ekonomi sebagai berikut:

1. Peningkatan dalam pendapatan per kapita masyarakat yaitu: tingkat pertumbuhan GDP pada satu tahun tertentu adalah melebihi dari tingkat pertumbuhan penduduk.

2. Perkembangan GDP yang berlaku dalam suatu masyarakat, dibarengi oleh perbaikan dan modernisasi dalam struktur ekonomi yang umumnya masih bercorak tradisional.

Professor Baran dalam Todaro (2000) memberikan definisi 
bahwa pertumbuhan ekonomi sebagai kenaikan output per kapita barang-barang material dalam suatu jangka waktu. Menurut Buchanan Ellis pertumbuhan ekonomi berarti pengembangan potensi pendapatan riil negara-negara berkembang dengan menggunakan investasi yang akan melahirkan berbagai perubahan dan memperbesar sumber-sumber produktif yang pada gilirannya menaikkan pendapatan riil per kapita. pendapatan per kapita didapat melalui jumlah pendapatan propinsi (Produksi Domestik Regional Bruto) dibagi dengan jumlah penduduk propinsi.

\section{Pengangguran}

Menurut Raper dalam Brotherhood (2002) pengangguran adalah penyebab kemiskinan terbesar dan perlu diberantas, tetapi hanya dapat diatasi salah satunya dengan cara menyediakan pekerjaan dan kesempatan kerja, daripada hanya sekedar himbauan atau slogan-slogan saja.

Pengangguran bukan semata-mata hanya masalah bagi mereka yang tidak memiliki pekerjaan, melainkan masalah bagi kita semua. Jika masyarakat tidak memiliki dana untuk dibelanjakan, maka perusahaan tidak dapat menjual produknya, dan dampaknya akan mempengaruhi seluruh perekonomian. Langkah pertama untuk mengurangi pengangguran adalah dengan mengakui bahwa pengangguran bukanlah akibat seseorang yang malas, melainkan masalah struktural.

Menurut Brotherhood (2002) Hal ini berarti, pemerintah mempunyai peran dalam menerapkan kebijakan yang sesuai. Jika pemerintah melakukan investasi dalam penyediaan lapangan kerja, hal ini tidak hanya akan menjaga stabilitas perekonomiannya, tetapi juga akan menciptakan banyak kesempatan bekerja. Untuk memperoleh pekerjaan, setiap individu memerlukan skill yang dibutuhkan pekerjaan tersebut, maka akses terhadap pelatihan sangat penting.

Menurut Arief dalam Gemmel (1992), Indonesia merupakan suatu kasus di mana pertumbuhan bertumpu pada industri padat modal dan pengeboran minyak bumi, ditambah dengan pengembangan pertanian yang cenderung hemat tenaga kerja. Jenis pengembangan demikian berarti bahwa permintaan akan tenaga kerja tidak terampil tetap rendah sehingga tingkat pengangguran bertambah, dan hal 
ini berarti bahwa tingkat kemiskinan hampir pasti naik. Maka perlu diciptakan kebijakan yang meningkatkan permintaan akan tenaga kerja tidak terampil agar memudahkan penduduk miskin menjual tenaga kerja mereka dan mengurangi jumlah penganggur. Dengan cara ini, kekuatan pasar akan mendukung kebijakan pengentasan kemiskinan.

\section{Kerangkapikir Konseptual}

Bila tingkat pendidikan seseorang tinggi maka hal tersebut dapat membuat ia lebih mudah memperoleh penghasilan yang dapat membawanya keluar dari garis kemiskinan. Penghasilan dalam hal ini pendapatan yang didapatnya dapat menambah pendapatan yang diperlukan dalam kehidupan seharihari dalam mencukupi kebutuhan sandang dan pangannya. Akumulasi pendapatan propinsi yang baik dengan kata lain pendapatan per kapita yang tinggi akan berdampak pada kesejahteraan seseorang.

Dalam kaitan itulah maka patut diduga tingkat pendidikan dan pendapatan per kapita mempunyai pengaruh yang negatif terhadap kemiskinan. Semakin tinggi tingkat pendidikan dan pendapatan per kapita maka semakin rendah kemiskinan, dalam arti kemiskinan penduduk tersebut berkurang.

Bila seseorang berada dalam keadaan menganggur berarti ia tidak mendapatkan tambahan penghasilan dalam memenuhi kebutuhan hidupnya. Terlihat bahwa apabila seseorang itu menganggur maka akan membuat ia terlihat miskin karena tidak bisa memenuhi kebutuhan pokok dalam sehari-hari.

Dalam kaitan itulah maka patut diduga pengangguran mempunyai pengaruh yang positif terhadap kemiskinan. Semakin tinggi pengangguran maka semakin tinggi pula kemiskinan.

Terdapat pengaruh yang menggambarkan antara tingkat pendidikan, pendapatan per kapita dan pengangguran terhadap kemiskinan. Semakin tinggi pengangguran maka semakin tinggi pula kemiskinan, sedangkan semakin tinggi tingkat pendidikan dan pendapatan per kapita maka semakin rendah kemiskinan. Hal ini merupakan kerangka yang logis karena agar kemiskinan dapat diatasi, maka patut diketahui dan dipahami faktor-faktor yang mempengaruhinya. 


\section{METODE PENELITIAN}

Penelitian ini terbatas pada pengujian sampai sejauh mana variabel tingkat pendidikan dan pengangguran

mempengaruhi variabel tidak bebas, kemiskinan. Analisis dilakukan dengan menggunakan data tahunan selama 5 tahun, dari tahun 2007 sampai dengan tahun 2011. Data-data yang digunakan dalam penelitian ini adalah data sekunder yang diperoleh dari Badan Pusat Statistik (BPS). Secara spesifik data yang digunakan adalah sebagai berikut :

\section{Kemiskinan (Pov)}

Data kemiskinan yang digunakan bersumber dari Biro Pusat Statistik (BPS) didapat melalui data jumlah penduduk miskin kota dan desa.

2. Tingkat Pendidikan (Edu)

Data pendidikan didapat melalui data dari Biro Pusat Statistik yaitu pendidikan yang ditamatkan penduduk pada 15 tahun ke atas dilihat pada tamatan SMA/MA dan sederajat karena pada hasil akhir pendidikan tersebut seseorang sudah siap untuk bekerja.

3. Pendapatan per Kapita (Y/cap) Data pendapatan per kapita didapat melalui jumlah pendapatan propinsi (Produksi Domestik Regional Bruto) dibagi dengan jumlah penduduk propinsi.

4. Pengangguran (Un)

Data pengangguran didapat melalui data bersumber dari Biro Pusat Statistik (BPS) yaitu data Pengangguran terbuka menurut pendidikan tertinggi yang ditamatkan. Pada penelitian ini juga melihat pada tamatan SMA/MA dan sederajat.

Analisis yang digunakan pada penelitian ini adalah analisis deskriptif-kualitatif terhadap data time series dan analisis kuantitatif. Analisis deskriptif-kualitatif disusun berdasarkan metode penelitian dengan pengujian terhadap data sekunder yang diperoleh dari berbagai sumber data, jurnal, artikel, buku, majalah, internet dan studi literatur ilmiah yang berkaitan dengan permasalahan yang sedang diteliti. Sedangkan untuk analisis kuantitatif digunakan alat bantu ekonometrika untuk mendapatkan gambaran yang jelas tentang hubungan antara variabel-variabel yang digunakan dalam penelitian ini.

\section{Spesifikasi Model Ekonometrik}

Model ekonometrik yang digunakan dalam penelitian ini 
diformulasikan sendiri oleh peneliti. Model ini digunakan untuk mengetahui bagaimana tingkat pendidikan dan pengangguran mempengaruhi kemiskinan. Model ekonometrik penelitian ini diformulasikan sebagai berikut:

$$
\begin{aligned}
& P o y=\beta_{0}+\beta_{t} E d u+\beta_{2}(Y / c a)_{t}+\beta 3 U \eta+\varepsilon_{t} \\
& \text { dimana : } \\
& \text { Pov }_{\mathrm{t}} \quad=\text { kemiskinan pada tahun } \mathrm{t} \\
& \mathrm{Edu}_{\mathrm{t}}=\text { tingkat pendidikan pada } \\
& \text { tahun } \mathrm{t} \\
& (\mathrm{Y} / \text { cap })_{\mathrm{t}}=\text { pendapatan per kapita } \\
& \text { pada tahun } \mathrm{t} \\
& \mathrm{Un}_{\mathrm{t}} \quad=\text { pengangguran pada } \\
& \text { tahun } \mathrm{t} \\
& \varepsilon_{t} \quad=\text { error terms }
\end{aligned}
$$

\section{HASIL DAN PEMBAHASAN \\ Interpretasi Model}

Pada bagian ini akan diungkapkan pengaruh tingkat pendidikan dan pengangguran terhadap kemiskinan di DKI Jakarta. Untuk pengolahan data, alat bantu yang digunakan adalah software SPSS.

Berdasarkan hasil pengolahan data, didapat persamaan regresi ganda sebagai berikut : $P o \gamma=\beta_{0}+\beta_{t} E d u+\beta_{2}\left(Y / c a p_{t}+\beta 3 U \eta+\varepsilon_{t}\right.$

$\mathbf{P o v}_{\mathbf{t}}=-1243.771-0.019569$ Edu - 0.004594 (Y/cap) + 132.1452 Un
Berikut ini adalah nilai-nilai hasil uji statistik lainnya, yaitu :

R-squared

0.933086

Adjusted R-squared $\quad 0.918747$

S.E. of regression

Sum squared resid

15111178

Log likelihood

Durbin-Watson stat

1.496422

R-squared

0.933086

\begin{tabular}{lr}
\hline \hline Adjusted R-squared & 0.918747 \\
\hline \hline S.E. of regression & 1038.927 \\
\hline \hline Sum squared resid & 15111178 \\
\hline \hline Log likelihood & -148.3061 \\
\hline \hline Durbin-Watson stat & 1.496422 \\
\hline \hline
\end{tabular}

Dari uji F-statistik yang signifikan sampai dengan tingkat kepercayaan 0.00000 dan nilai Adj.R2 yang sebesar $91.9 \%$ dapat dinyatakan bahwa persamaan model yang terbentuk cukup baik. Persamaan tersebut juga menghasilkan tanda -/+ sebagaimana yang diharapkan, yakni kenaikan tingkat pendidikan dan pendapatan per kapita akan berakibat kemiskinan menurun. Adapun kenaikan pengangguran yang bertanda positif akan mengakibatkan kemiskinan menguat. Ini berarti bahwa kemiskinan dapat dijelaskan dengan 
cukup baik oleh pergerakan variabel-variabelnya.

Uji Heteroskedastisitas dilakukan dengan cara uji White Heterocedasticity Test. Hasil uji tersebut menghasilkan nilai sebagai berikut :

Obs*R-squared $: 6.963660$

Probability : 0.324221

Hasil uji tersebut dengan P-Value sama dengan 0.324221 menunjukkan bahwa $\mathrm{H}_{0}$ yang menyatakan tidak ada heteroskedastisitas

(homoskedastisitas) pada residual diterima pada tingkat signifikansi 5 \%. Jadi, dengan tingkat keyakinan $95 \%$ pada data tersebut tidak terjadi heteroskedastisitas.

Distribusi residual yang dihasilkan menunjukkan bahwa asumsi normalitas residual terpenuhi. Hal ini terlihat dari metode histogram dan Jarque-Berra yang digunakan, dimana nilai-P yang diperoleh cukup tinggi. Lihat lampiran 3. HO : error term terdistribusi normal, dan $\mathrm{H} 1$ : error term tidak terdistribusi normal. Nilai$P$ sebesar 0.488974 lebih besar dari $\alpha=5 \%$, P-value $=0.488974>$ 0.05 maka terima $\mathrm{HO}$. dengan tingkat keyakinan $95 \%$ maka dapat dikatakan error term terdistribusi normal.

\section{KESIMPULAN}

Berdasarkan pada teori-teori dan pembuktian baik secara empiris maupun ekonomi mengenai pengaruh tingkat pendidikan, pendapatan per kapita dan pengangguran terhadap kemiskinan di DKI Jakarta, maka dapat disimpulkan bahwa tingkat pendidikan dan pendapatan per kapita di DKI Jakarta mempunyai kecenderungan untuk meningkat setiap tahunnya. Terdapat pengaruh yang negatif tingkat pendidikan dengan pendapatan per kapita pada periode penelitian. Pengangguran mempunyai dampak yang positif terhadap kemiskinan. Walaupun pada periode penelitian jumlah pengangguran mengalami penurunan tiap tahunnya. Karena pemerintah banyak memberikan bantuan guna menunjang pertumbuhan ekonomi dan mendorong berkembangnya kegiatan ekonomi masyarakat.

\section{DAFTAR PUSTAKA}

Badan Pusat Statistik, 2000. Laporan Perekonomian Indonesia 2000, Jakarta.

Brotherhood of St. Laurence, 2002. Unemployment and Poverty, Australia. 
Doshi, Kokila P. 2000. Inequality and Economic Growth, University of San Diego.

Gemmell, Norman, 1992. IImu Ekonomi Pembangunan Beberapa Survey. Jakarta : Penerbit PT Pustaka.

Gillis, Malcom.et.al, 2000. Economic of Development, New York : WW Norton \& Company Inc.

Jhingan, M.L., 1994. Ekonomi Pembangunan Dan Perencanaan, Jakarta: PT Raja Grafindo Persada
Todaro, Michael P., 2000. Pembangunan Ekonomi Di Dunia Ketiga, Edisi Ketujuh, Jilid 1, Jakarta: Penerbit Erlangga

World Development Report, 1990. Poverty, Washington DC: Oxford University Press.

www.bps.go.id 